\title{
Genetic Variation in Clinical Varicella-Zoster Virus Isolates Collected in Ireland Between 2002 and 2003
}

\author{
Michael J. Carr, ${ }^{1}$ Grace P. McCormack, ${ }^{2}$ and Brendan Crowley ${ }^{3 *}$ \\ ${ }^{1}$ Department of Clinical Microbiology, St. James's Hospital, Dublin, Ireland \\ ${ }^{2}$ Department of Biology, National University of Ireland, Maynooth, Kildare, Ireland \\ ${ }^{3}$ National Virus Reference Laboratory, University College Dublin, Belfield, \\ Dublin and Department of Clinical Microbiology, St. James's Hospital, Dublin, Ireland
}

Analysis of genetic variation in 16 varicella-zoster virus (VZV) isolates selected at random and circulating in the Irish population between March 2002 and February 2003 was carried out. A 919 bp fragment of the glycoprotein $\mathrm{E}$ gene (open reading frame 68) encompassing codon 150, at which a non-synonymous mutation defines the escape mutant VZV-MSP, and including two other epitope regions $\mathrm{e} 1$ and $\mathrm{c} 1$, was sequenced. No new single nucleotide polymorphisms (SNPs) were detected, indicating stability of these epitopes in clinical isolates of VZV. However, when four informative polymorphic markers consisting of defined regions from genes $1,21,50$, and 54 were sequenced 14 variable nucleotide positions were identified. Phylogenetic analysis showed the presence of three highly supported clades $A$, $B$, and $C$ circulating in the Irish population. Approximately one third $(6 / 16 ; 37.5 \%)$ of the Irish VZV isolates in this study belonged to genotype C, 4/16 (25\%) to genotype $A$, and $4 / 16(25 \%)$ to genotype B. A smaller number 2/16 (12.5\%) belonged to genotype $\mathrm{J} 1$. This indicates remarkable heterogeneity in the Irish population given the small sample size. No evidence was found to suggest any of the 16 isolates was a recombinant. These findings have implications for the model of geographic isolation of VZV clades to certain regions as the circulating Irish VZV population appears to comprise approximately equal numbers of each of the main genotypes. This data is inconsistent with a model of strict geographical separation of VZV genotypes and suggests that VZV diversity is more pronounced in certain areas than had been thought previously. J. Med. Virol. 73:131-136, 2004. ๑) 2004 Wiley-Liss, Inc.

KEY WORDS: varicella-zoster virus; genotyping; single nucleotide polymorphisms; molecular epidemiology

\section{INTRODUCTION}

Varicella-zoster virus (VZV) is a member of the $\alpha$ herpesvirus subfamily of Herpesviridae. It is the aetiological agent of chickenpox (varicella) in childhood, after which the virus enters a latent state in the sensory ganglia; decades later, the same virus may reactivate to cause shingles (zoster). The VZV genome is a $125 \mathrm{~kb}$ linear double-stranded DNA molecule and encodes approximately 71 gene products [Davison and Scott, 1986]. VZV is an extremely stable virus. The nucleotide diversity of VZV has been estimated at 0.00063 which is similar to the human genome (0.00078) and at least five times less than that of any other member of the human herpes virus family [Barrett-Muir et al., 2002]. This low rate of divergence probably reflects the few replicative cycles VZV undergoes during its life cycle in the host.

However, genetic diversity among strains of VZV has been demonstrated. This genetic variation, predominantly a result of single nucleotide polymorphisms (SNPs), has been defined by the presence or absence of restriction sites, such as a $P s t I$ site in gene 38 and a $B g l \mathrm{I}$ site in open reading frame (ORF) 54, and also by an alteration in the number of repeat elements within the five repeat region in the VZV genome [Adams et al., 1989; Hondo et al., 1989; Takayama et al., 1996]. These features were used to distinguish the live attenuated Japanese Oka vaccine and wild type viruses circulating in the United States and United Kingdom [LaRussa et al., 1992; Hawrami et al., 1996]. Furthermore, a mixture of genetically distinct strains were shown to be circulating in the East End of London (United Kingdom), where $20 \%$ of VZV strains were positive for a $B g l \mathrm{I}$ restriction site in gene 54 [Hawrami et al., 1997].

*Correspondence to: Dr. Brendan Crowley, Department of Clinical Microbiology, St. James's Hospital, Dublin 8, Ireland.

E-mail: bcrowley@stjames.ie

Accepted 27 November 2003

DOI 10.1002/jmv.20048

Published online in Wiley InterScience

(www.interscience.wiley.com) 
However, $60 \%$ of strains from zoster presenting in immigrants whose primary infection occurred in the Indian subcontinent, Africa, and the Caribbean were $B g l$ I positive as compared with only $10 \%$ of viruses from cases of zoster in patients brought up in the United Kingdom. Recently a heteroduplex mobility assay (HMA) was used to identify variants of VZV circulating in the United Kingdom and elsewhere [BarrettMuir et al., 2001, 2002]. Polymorphisms identified by HMA were confirmed and characterised by nucleotide sequence analysis, allowing identification of additional SNPs which can be used to genotype VZV strains. Furthermore, phylogenetic analysis distinguished at least three major clades (A, B, and C) among VZV isolates collected worldwide [Barrett-Muir et al., 2003]. Variation in the VZV genotype appeared to be associated closely with the geographical region in which infection was acquired, with strains in clade A forming an African-Asian grouping, whereas strains in clades B and $\mathrm{C}$ were found mainly in European populations.

Little is known about differences in properties of different strains of wild type VZV viruses. However, a mutation in a functionally important gene may have dramatic effects on biological and clinical phenotype. In 1998, a VZV mutant virus (VZV-MSP) was discovered in Minneapolis-St. Paul, Minnesota; the virus had a missense mutation in the preponderant surface glycoprotein called gE [Santos et al., 1998]. A SNP (G > A) in codon 150 of ORF 68 resulted in an amino acid change of aspartic acid to asparagine. This mutation led to a lost Bcell epitope in the $\mathrm{gE}$ ectodomain. Furthermore the mutant virus had a recognisable phenotype consisting of accelerated cell spread in both cell culture and the SCIDhu (severe combined immunodeficient mouse with a human skin implant) model of VZV pathogenesis as well as a different pattern of egress, as shown by scanning electron microscopy [Santos et al., 2000]. The prevalence and clinical significance of the mutation in this epitope is unknown. Therefore we examined clinical isolates of VZV collected in the Republic of Ireland for this mutation. We also investigated genetic variation in these VZV isolates by SNP analysis using a representative subset of gene markers. Our findings have implications for the association of VZV clades to specific geographical regions.

\section{MATERIALS AND METHODS}

\section{Patients and Clinical Samples}

Isolates of VZV from 16 Irish patients were analysed. All samples were collected as swabs of vesicle fluid in viral transport medium between March 2002 and February 2003, and processed in the National Virus Reference Laboratory, University College, Dublin. There was no epidemiological relationship, either in time or place, between the patients. All cases of varicella were sporadic. Specimens were collected from patients with varicella at least 8 weeks apart and from different regions of the country. Clinical characteristics of these patients were reviewed. Varicella was defined as vesicular eruption with a generalised onset and no dermatomal distribution. Herpes zoster was defined as the appearance of typical vesicular skin lesions with a dermatomal distribution. Disseminated herpes zoster consisted of six skin lesions beyond the boundaries of the primary dermatome and/or visceral involvement.

\section{VZV DNA Isolation and Polymerase Chain Reaction}

VZV DNA was isolated from $200 \mu \mathrm{l}$ of virus infected cells using the QIAamp DNA Mini Kit (Qiagen, Crawley, United Kingdom) according to the manufacturer's instructions. DNA amplification reactions were carried out in $50 \mu \mathrm{l}$ volumes with $1 \mu \mathrm{l}$ of extract or control DNA, $2.5 \mathrm{U}$ of HotStarTaq DNA polymerase (Qiagen), $1 \mu \mathrm{M}$ of each forward and reverse primer, $200 \mu \mathrm{M}$ concentrations of each deoxynucleoside triphosphate, and $1.5 \mathrm{mM}$ $\mathrm{MgCl}_{2}$. Thermal cycling comprised an initial hot start at $95^{\circ} \mathrm{C}$ for $15 \mathrm{~min}$, followed by $35-40$ cycles of $94^{\circ} \mathrm{C}$ for $1 \mathrm{~min}, 55^{\circ} \mathrm{C}$ for $1 \mathrm{~min}$, and then $72^{\circ} \mathrm{C}$ for $1 \mathrm{~min}$, with a final extension step at $72^{\circ} \mathrm{C}$ for $10 \mathrm{~min}$. The PCR products were visualized on an UV transilluminator following agarose gel electrophoresis in $2 \%(\mathrm{w} / \mathrm{v})$ gels containing $0.5 \mu \mathrm{g}$ ethidium bromide $\mathrm{ml}^{-1}$ in $0.5 \times$ Trisborate-EDTA running buffer. To assess the MSP status of the clinical samples a $919 \mathrm{bp}$ fragment of the $\mathrm{gE}$ gene (ORF68) was amplified using primer pairs, gE-F and gE$\mathrm{R}$ (Table I) [Shankar et al., 2001]. In addition, informative polymorphic markers from VZV genes $1,21,50$, and 54 were employed for genotyping and these amplify

TABLE I. Oligonucleotide Primers Used to Amplify and Sequence Genes in Varicella-Zoster Virus (VZV) Isolates

\begin{tabular}{|c|c|c|c|c|}
\hline Primer & Sequence $\left(5^{\prime}-3^{\prime}\right)$ & $\begin{array}{l}\text { Nucleotide } \\
\text { position }\end{array}$ & $\begin{array}{l}\text { Amplicon } \\
\text { size (bp) }\end{array}$ & Reference \\
\hline GE-F & TCACACCGATGAAGACAAAC & $115921-115940$ & & \\
\hline GE-R & CCACATATGAAACTCAGCCC & $116839-116820$ & 919 & Shankar et al. [2001] \\
\hline VZV-1F & TCAGCTGGCTTTTCTAAGAATTCG & $427-450$ & & \\
\hline VZV-1R & TATTTTTGGGATCCGCAATGTC & $932-911$ & 506 & Barrett-Muir et al. [2002] \\
\hline $\mathrm{VZV}-21 \mathrm{~F}$ & TAATGAATTGAGGCGCGGTTTA & $33497-33518$ & & \\
\hline VZV-21R & CACGTGTAGCTCCAAAAACCTAGG & 33999-33976 & 503 & Barrett-Muir et al. [2002] \\
\hline VZV-50F & CGCACCCAAAGTGAACATCAT & $87736-87756$ & & \\
\hline VZV-51R & TCTCGGATGTCAAATATGTTACGA & $88250-88227$ & 515 & Barrett-Muir et al. [2002] \\
\hline VZV-54BgIIF+ & CGTAATGCATAACAGGCCAACAC & $95005-95027$ & & \\
\hline VZV-54BgIIR+ & GAAACCTGGCGTCAAACATTACA & $95501-95479$ & 497 & Barrett-Muir et al. [2002] \\
\hline
\end{tabular}


$500 \mathrm{bp}$ fragments of the VZV genome (Table I) [BarrettMuir et al., 2002]. Oligonucleotide primers were manufactured by Sigma-Genosys (Sigma-Genosys, Cambs, United Kingdom) and PCR products were purified using a MinElute PCR purification kit (Qiagen).

\section{DNA Sequencing and Phylogenetic Analysis}

Automated DNA sequencing was carried out on an ABI Prism 3730XL DNA Analyser (Perkin Elmer Applied Biosystems, UK, Warrington, UK). Sequencing reactions of purified PCR products were performed in a $20 \mu \mathrm{l}$ reaction volume containing $8 \mu \mathrm{l}$ of the Big Dye terminator mix (version 3.1 Chemistry), 3.2 pmol of the forward primer, and $100 \mathrm{ng}$ of PCR product template. The GenAmp PCR system 9600 was programmed for 5 min at $96^{\circ} \mathrm{C}$, then 25 cycles of $96^{\circ} \mathrm{C}$ for $30 \mathrm{sec}, 50^{\circ} \mathrm{C}$ for $15 \mathrm{sec}, 55^{\circ} \mathrm{C}$ for $4 \mathrm{~min}$. The extension products were purified on spin columns, dried down, and resuspended in template suppression buffer (Perkin Elmer). Sequence traces were analysed using Chromas v. 1.45 DNA software (Conor McCarthy, Griffith University, Australia) and sequence polymorphisms identified by ClustalX alignment [Thompson et al., 1997] with the relevant regions of the Dumas vaccine strain [Davison and Scott, 1986]. A multiple alignment containing four gene regions (ORFs 1, 21, 50, and 54) in order, was assembled, aligned, and optimised using MacClade 4.03 [Maddison, 2001]. Phylogenetic reconstructions, employing maximum parsimony and maximum likelihood, were carried out using PAUP* 4.0b10 [Swofford, 1998] with the Dumas sequence employed as outgroup. A heuristic search strategy was employed using random sequence addition with ten replicated and TBR branch swapping in effect. The model of evolution for likelihood analysis was chosen using Modeltest version 3.06 [Posada and Crandall, 1998]. The chosen model of evolution (K80) included two substitution types with the transition transversion ratio estimated at 14.0 , no rate variation across sites, and equal base frequencies. Model parameters were then estimated using a heuristic search strategy and selecting those with the highest likelihood. Bootstrapping was employed to examine tree robustness under both methods with 1000 replicates performed.

The following accession numbers have been assigned: GenBank entry for genotype C1 (SNP95118) (VZV ORF 54) is AY379115, and GenBank entry for genotype B1 (SNP95241) (VZV ORF 54) is AY379116.

\section{RESULTS}

All 16 patients from whom VZV was isolated were Irish (Table II). Five patients presented with varicella, whereas 11 had herpes zoster, of whom one had cutaneous dissemination. No visceral disseminations were observed, even among immunocompromised patients, and no death was related to VZV infection. The mutant strain VZV-MSP, associated with increased virulence in an animal model, was not detected in any of the 16 clinical isolates. However, one polymorphism, the synonymous nucleotide substitution of $\mathrm{T}>\mathrm{C}$ at codon 220 in ORF68 (SNP116467; Table III), was identified in the epitope-encoding region of the $\mathrm{gE}$ gene in eight isolates.

To determine the distribution of genotypes in the Irish VZV isolates a subset of informative polymorphic markers in ORFs 1, 21, 50, and 54 were analysed. The results of the phylogenetic analysis and genotyping are shown in Figure 1 and Table III, respectively. Significant genetic diversity, including new genotypes were identified among these isolates (Table III). Approximately one third 6/16 (37.5\%) of the Irish VZV isolates in this study belonged to genotype C, 4/16 (25\%) to genotype $\mathrm{A}$, and an equal number were genotype $\mathrm{B}$ 4/16 (25\%). A smaller number 2/16 (12.5\%) belonged to genotype J1. Three trees were produced under parsimony each differing only in the relative positions of sequences belonging to B and B1 genotypes (Fig. 1). Relationships

TABLE II. Characteristics of VZV Infections in Irish Patients From Whom VZV Was Isolated Between March 2002 and February 2003

\begin{tabular}{|c|c|c|c|c|c|c|}
\hline VZV isolate & Sex & Age (years) & Nationality & Immunocompromised & $\begin{array}{l}\text { Varicella (V) } \\
\text { or zoster (Z) }\end{array}$ & History of varicella \\
\hline 01 & $\mathrm{M}$ & 82 & Irish & - & $\mathrm{Z}$ & Childhood in Ireland \\
\hline 02 & $\mathrm{M}$ & 4 & Irish & - & $\mathrm{V}$ & - \\
\hline 03 & $\mathrm{~F}$ & 53 & Irish & Yes & $\mathrm{Z}$ & Childhood in Ireland \\
\hline 04 & M & 1 & Irish & - & V & - \\
\hline 05 & $\mathrm{~F}$ & 71 & Irish & Yes & $\mathrm{Z}$ & NA \\
\hline 06 & $\mathrm{M}$ & 31 & Irish & Yes & $\mathrm{Z}^{\mathrm{a}}$ & Childhood in Ireland \\
\hline 07 & $\mathrm{~F}$ & 61 & Irish & - & $\mathrm{Z}$ & NA \\
\hline 08 & $\mathrm{M}$ & 61 & Irish & - & $\mathrm{Z}$ & NA \\
\hline 09 & M & 70 & Irish & - & $\mathrm{Z}$ & NA \\
\hline 10 & $\mathrm{~F}$ & 34 & Irish & Yes & $\mathrm{Z}$ & Childhood in Ireland \\
\hline 11 & $\mathrm{M}$ & 61 & Irish & - & $\mathrm{Z}$ & NA \\
\hline 12 & $\mathrm{~F}$ & 5 & Irish & - & V & - \\
\hline 13 & $\mathrm{M}$ & 5 & Irish & - & $\mathrm{V}$ & - \\
\hline 14 & M & 1 & Irish & - & $\mathrm{V}$ & - \\
\hline 15 & M & 75 & Irish & - & $\mathrm{Z}$ & - \\
\hline 16 & M & 74 & Irish & - & $\mathrm{Z}$ & Childhood in Ireland \\
\hline
\end{tabular}

NA, not available.

${ }^{a}$ Disseminated cutaneous zoster. 


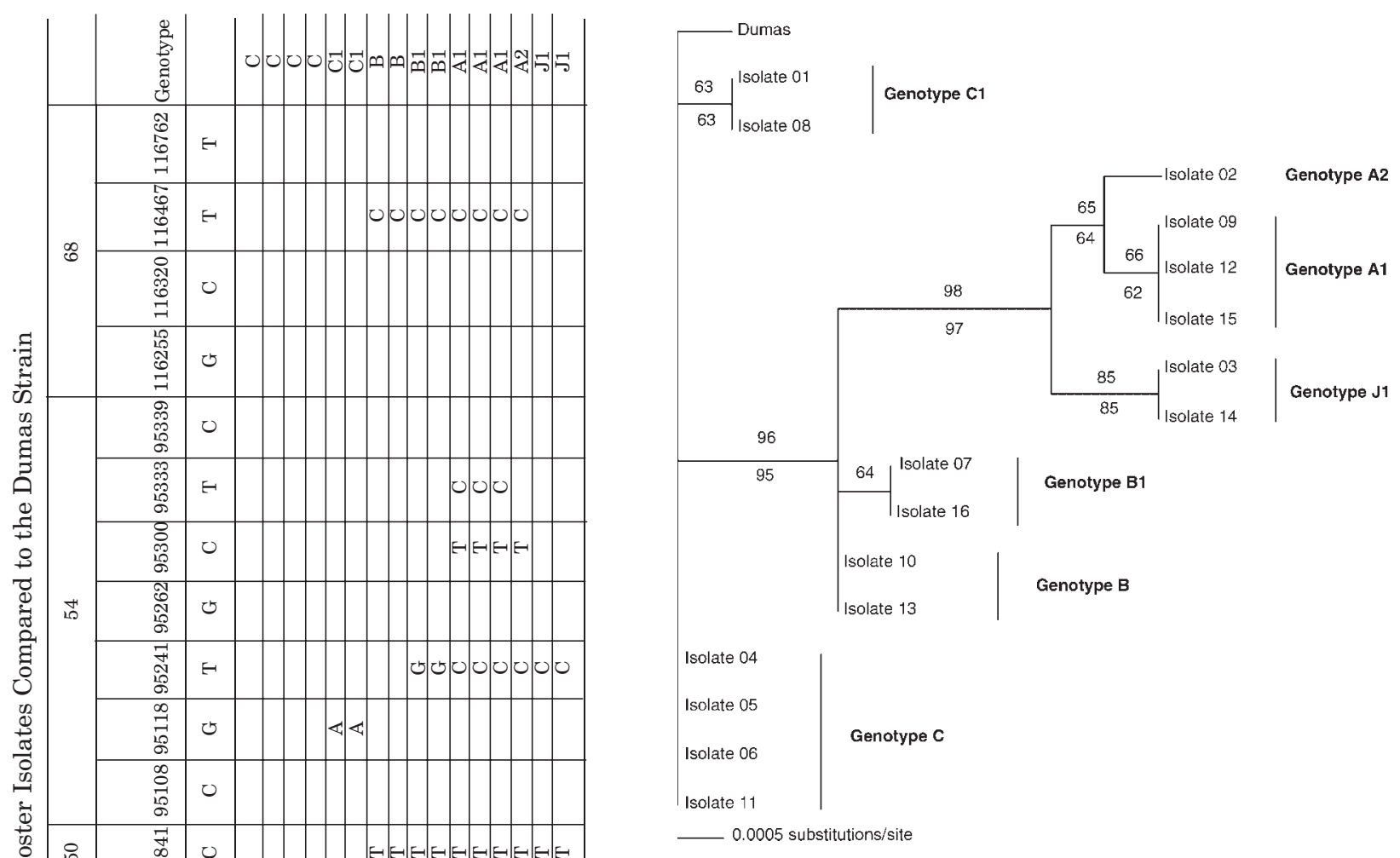

Fig. 1. Phylogenetic reconstruction of Irish varicella-zoster virus (VZV) sequences under maximum likelihood. Numbers on the branches represent bootstrap proportions (BP) under likelihood while those beneath the branches represent BPs under parsimony (1000 replicates).

present under parsimony were highly congruent to those seen under likelihood from which a single tree was produced. Genotypes A, B, and C were separated under both methods with high bootstrap support $(>90 \mathrm{BP}$, $\mathrm{BP}=$ bootstrap proportion). While bootstrap support for genotype A was not unimpeachable $(<70 \mathrm{BP})$ the presence of a Sau96I restriction site in ORF 21 (SNP 33646) further subdivided isolates of this genotype into A1 and A2 (Fig. 1). Genotype J1 was more closely related to genotype $\mathrm{A}$ than genotypes $\mathrm{B}$ and $\mathrm{C}$ falling into the same highly supported clade. Furthermore, two genotypes not reported previously were also identified. A synonymous G > A mutation in ORF 54 (SNP 95118) subdivided clade $\mathrm{C}$ viruses into genotype $\mathrm{C}$ and the new genotype $\mathrm{C} 1$, and a $\mathrm{T}>\mathrm{G}$ mutation (SNP 95241) in ORF 54 subdivided clade $\mathrm{B}$ viruses into $\mathrm{B}$ and the new genotype, B1 (Fig. 1 and Table III). Bootstrap support for these divisions was $<70 \mathrm{BP}$ and the separation of genotypes B and B1 was not supported by parsimony. No evidence was found to indicate that any of the VZV isolates circulating in the Irish population was a recombinant.

\section{DISCUSSION}

The data presented in this study using informative polymorphic markers in genes $1,21,50$, and 54 show the high degree of heterogeneity among VZV isolates 
circulating in Ireland between March 2002 and February 2003. Previous SNP analyses of this kind have shown remarkable genetic uniformity of VZV isolates, as for example in the African/Asian regions of the world, where genotype A predominates [Barrett-Muir et al., 2002]. In contrast, VZV populations in the United Kingdom and Brazil were more heterogeneous with strains of the three main genotypes A, B, and C [BarrettMuir et al., 2002, 2003]. The majority of viruses from the United Kingdom were genotype C, whereas among Irish isolates there were almost equal proportions of the main genotypes $\mathrm{A}, \mathrm{B}$, and $\mathrm{C}$, at 25,25 , and $37.5 \%$, respectively. Furthermore, two isolates were genotype J1, only reported previously in Japanese samples [Barrett-Muir et al., 2002]. Even more surprising was the finding of two novel genotypes derived from clades B and C, namely B1 and $\mathrm{C} 1$, respectively. It has been suggested that the mixture of viruses in the United Kingdom related to the pattern of immigration to those countries [Barrett-Muir et al., 2003]. This hypothesis is supported by the recent spread in London of clade A strains, which appeared to coincide with immigration from Africa and the Indian subcontinent to the United Kingdom [Hawrami et al., 1997]. In our study, all patients were Irish. However, three of the patients with varicella were school children, and could have acquired infection having mixed with immigrant school children from Africa or Asia, thereby accounting for genotypes A1 and A2 (Fig. 1). On the other hand, it is notable that the novel genotypes B1 and C1 occurred in adults with herpes zoster, two of whom had a past history of varicella in childhood while living in Ireland. This suggests that these novel genotypes may have evolved independently. Unfortunately, VZV isolates from previous years were unavailable to ascertain if there has been a temporal change in the composition of genotypes. Further study is needed to investigate the epidemiology of VZV infections in Ireland, in particular to determine if imported infections alone account for the genetic diversity of isolates collected in Ireland.

Genotype A members are distinguished by the possession of a $B g l \mathrm{I}$ restriction site in gene 54 and are particularly prevalent in individuals of African and Asian descent [Quinlivan et al., 2002]. The novel T $>$ G mutation (SNP 95241) in ORF 54 characteristic of genotype B1 would not be detected by PCR-RFLP. It is conceivable that some of the $B g l \mathrm{I}^{-}$populations identified in previous studies employing solely restriction enzyme analysis and not direct DNA sequencing may have overlooked this SNP [Hawrami et al., 1997; Quinlivan et al., 2002; Sauerbrei et al., 2003].

In contrast to the heterogeneity of VZV genotypes, our results indicate that VZV glycoprotein $\mathrm{E}(\mathrm{gE})$ epitopes $\mathrm{e} 1$ and $\mathrm{c} 1$ are conserved in Irish clinical isolates. VZVMSP has an amino acid substitution in position 150 of the surface glycoprotein $\mathrm{gE}$, and has been shown to have attributes consistent with increased virulence in a mouse model [Santos et al., 2000]. In our study, a $919 \mathrm{bp}$ fragment of the glycoprotein gE gene (ORF 68) encompassing the non-synonymous mutation $\mathrm{G}>\mathrm{A}$ at codon 150 and the two epitopes e 1 and $\mathrm{c} 1$ was sequenced. No non-synonymous mutations were detected, although $50 \%$ of isolates had the synonymous nucleotide polymorphism of $\mathrm{T}>\mathrm{C}$ in codon 120 of ORF 68, found in previous studies to be a common polymorphism [Shankar et al., 2001; Faga et al., 2001]. It has been suggested that antibody escape variant viruses like VZV-MSP may arise from selective antibody pressure over prolonged periods of time in immunocompromised hosts [Ciurea et al., 2000]. These authors found the same amino acid substitution in laboratory-derived antibody escape glycoprotein mutants as seen in the VZV-MSP variant. However, no such mutant was found in our study, which included 11 patients with herpes zoster, four of whom were immunocompromised. It is possible that VZV-MSP is a previously unrecognised subpopulation of VZV that has been circulating for many years. Whether it has increased replicative fitness is not known. Larger studies need to be conducted to ascertain the prevalence and clinical significance of this mutant virus.

Our findings have implications for the model of geographic isolation of VZV clades to certain regions as the circulating Irish VZV population appears to comprise approximately equal numbers of each of the main genotypes. This data are inconsistent with a model of strict geographical separation of VZV genotypes [Faga et al., 2001; Quinlivan et al., 2002; Wagenaar et al., 2003] and suggests that VZV diversity in more pronounced in certain areas than had been thought previously.

\section{ACKNOWLEDGMENTS}

The authors thank the National Virus Reference Laboratory in University College Dublin for providing the varicella-zoster isolates. The authors also thank Professor Seamus Fanning, University College Dublin, Dr. Philip Mortimer and Dr. Jonathan Clewley, Health Protection Agency, Colindale, London, for their assistance in preparing the manuscript.

\section{REFERENCES}

Adams SG, Dohner DE, Gelb LD. 1989. Restriction fragment differences between the genomes of the Oka varicella vaccine virus and American wild-type varicella-zoster virus. J Med Virol 29: $38-45$.

Barrett-Muir W, Hawrami K, Clarke J, Breuer J. 2001. Investigation of varicella-zoster virus variation by heteroduplex mobility assay. Arch Virol Suppl 17:17-25.

Barrett-Muir W, Nichols R, Breuer J. 2002. Phylogenetic analysis of varicella-zoster virus: Evidence of intercontinental spread of genotypes and recombination. J Virol 76:1971-1979.

Barrett-Muir W, Scott FT, Aaby P, John J, Matondo P, Chaudhry QL, Siqueira M, Poulsen A, Yaminishi K, Breuer J. 2003. Genetic variation of varicella-zoster virus: Evidence for geographical separation of strains. J Med Virol 70(Suppl 1):S42-S47.

Ciurea A, Klenerman P, Hunziker L, Horvath E, Senn BM, Ochsenbein AF, Hengartner H, Zinkernagel RM. 2000. Viral persistence in vivo through selection of neutralizing antibody-escape variants. Proc Natl Acad Sci USA 14:2749-2754.

Davison AJ, Scott JE. 1986. The complete DNA sequence of varicellazoster virus. J Gen Virol 67:1759-1816.

Faga B, Maury W, Bruckner DA, Grose C. 2001. Identification and mapping of single nucleotide polymorphisms in the varicella-zoster virus genome. Virology 280:1-6. 
Hawrami K, Harper D, Breuer J. 1996. Typing of varicella zoster virus by amplification of DNA polymorphisms. J Virol Methods 57:169174 .

Hawrami K, Hart IJ, Pereira F, Argent S, Bannister B, Bovill B, Carrington D, Ogilvie M, Rawstorne S, Tryhorn Y, Breuer J. 1997. Molecular epidemiology of varicella-zoster virus in East London, England, between 1971 and 1995. J Clin Microbiol 35:2807-2809.

Hondo R, Yogo Y, Yoshida M, Fujima A, Itoh S. 1989. Distribution of varicella-zoster virus strains carrying a PstI-site-less mutation in Japan and DNA change responsible for the mutation. Jpn J Exp Med 59:233-237.

LaRussa P, Lungu O, Hardy I, Gershon A, Steinberg SP, Silverstein S. 1992. Restriction fragment length polymorphism of polymerase chain reaction products from vaccine and wild-type varicella-zoster virus isolates. J Virol 66:1016-1020.

Maddison DR, Maddison WP. 2001. MacClade 4.0. Sunderland: Sinauer Associates Inc.

Posada D, Crandall KA. 1998. MODELTEST: Testing the model of DNA substitution. Bioinformatics 14:817-818.

Quinlivan M, Hawrami K, Barrett-Muir W, Aaby P, Arvin A, Chow VT, John TJ, Matondo P, Peiris M, Poulsen A, Siqueira M, Takahashi M, Talukder Y, Yamanishi K, Leedham-Green M, Scott FT, Thomas SL, Breuer J. 2002. The molecular epidemiology of varicella-zoster virus: Evidence for geographic segregation. J Infect Dis 186:888894.

Santos RA, Padilla JA, Hatfield C, Grose C. 1998. Antigenic variation of varicella zoster virus $\mathrm{Fc}$ receptor $\mathrm{gE}$ : Loss of a major B cell epitope in the ectodomain. Virology 249:21-31.
Santos RA, Hatfield CC, Cole NL, Padilla JA, Moffat JF, Arvin AM Ruyechan WT, Hay J, Grose C. 2000. Varicella-zoster virus gE escape mutant VZV-MSP exhibits an accelerated cell-to-cell spread phenotype in both infected cell cultures and SCID-hu mice. Virology 275:306-317.

Sauerbrei A, Eichhorn U, Gawellek S, Egerer R, Schacke M, Wutzler P. 2003. Molecular characterisation of varicella-zoster virus strains in Germany and differentiation from the Oka vaccine strain. J Med Virol 71:313-319.

Shankar V, Fisher S, Forghani B, Vafai A. 2001. Nucleotide sequence analysis of varicella-zoster virus glycoprotein $\mathrm{E}$ epitope coding regions. Vaccine 19:3830-3833.

Swofford DL. 1998. PAUP*. Phylogenetic analysis using parsimony (*and other methods). Sunderland, Massachusetts: Sinauer Associates.

Takayama M, Takayama N, Inoue N, Kameoka Y. 1996. Application of long PCR method of identification of variations in nucleotide sequences among varicella-zoster virus isolates. J Clin Microbiol 34:2869-2874.

Thompson JD, Gibson TJ, Plewniak F, Jeanmougin F, Higgins DG. 1997. The CLUSTALX windows interface: Flexible strategies for multiple sequence alignment aided by quality analysis tools. Nucleic Acids Research 25:4876-4882.

Wagenaar TR, Chow VT, Buranathai C, Thawatsupha P, Grose C. 2003. The out of Africa model of varicella-zoster virus evolution: Single nucleotide polymorphisms and private alleles distinguish Asian clades from European/North American clades. Vaccine 21: $1072-1081$. 